\title{
Hepatitis B Surface Antigen Should Not Be the Only Sought Marker to Distinguish Blood Donors towards Hepatitis B Virus Infection in High Prevalence Area
}

\author{
K. S. Somda*, A. K. Sermé, A. Coulibaly, K. Cissé, A. Sawadogo, A. R. Sombié, A. Bougouma \\ Hepato-Gastroenterology Unit, Teaching Hospital Yalgado Ouédraogo, Ouagadougou, Burkina Faso \\ Email: *sosthenesomda@gmail.com
}

How to cite this paper: Somda, K.S., Sermé, A.K., Coulibaly, A., Cissé, K., Sawadogo, A., Sombié, A.R. and Bougouma, A. (2016) Hepatitis B Surface Antigen Should Not Be the Only Sought Marker to Distinguish Blood Donors towards Hepatitis B Virus Infection in High Prevalence Area. Open Journal of Gastroenterology, 6, 362372.

http://dx.doi.org/10.4236/ojgas.2016.611039

Received: September 30, 2016

Accepted: November 27, 2016

Published: November 30, 2016

Copyright $\odot 2016$ by authors and Scientific Research Publishing Inc. This work is licensed under the Creative Commons Attribution International License (CC BY 4.0).

http://creativecommons.org/licenses/by/4.0/

(c) (i) Open Access

\section{Abstract}

Since its discovery by Blumberg in 1965, the hepatitis B surface antigen (HBsAg) is used as the fingerprint of hepatitis B infection. Occult hepatitis B infection (OBI) is defined by a viral replication (DNA detectable) in the absence of HBsAg. Burkina Faso is a high endemic area where the prevalence is higher than $14 \%$. At the National Center for Blood Transfusion (NCBT) of Ouagadougou, HBsAg is the only sought marker used to distinguish donors towards Hepatitis B Virus (HBV). Acceptation of blood donation is based specifically on the absence of HBsAg, which exposes to the risk of HBV transmission during transfusion. The goal of this study is to evaluate this risk by determining the prevalence of OBI in blood donors. Patients and Methods: It was a five-month prospective study on blood donations collected from January to May 2016. The HBc antibody has been sought in the serums of negative HBsAg donors. The measure of B DNA by Real Time PCR (polymerase chain reaction) and that of antibodies anti-HBs have been proposed to anti-HBc positive donors. Abdominal ultrasound, the transaminases, prothrombin level, alphafeto-proteins, hepatic fibrosis have been proposed to donors who were detectable for the DNA. Sociodemographic parameters have been collected. The test costs were borne by donors who were recalled by phone to adhere to the study. Results: Among 1980 negative donors HBsAg, 872 (44\%) were positive for anti-HBc. 160 on 872 donors were received for consultation, among which $76(76 / 160)$ were able to realise DNA which was detectable in 25 donors on 76 , thus a prevalence of $\mathbf{3 2 . 8 \%}$. The mean value of DNA was 953 $\mathrm{IU} / \mathrm{ml}$. Physical examination and hepatic ultrasounds were normal except a case where hepatic steatosis was found. The biologic standard hepatic results were in normal range. None of the patient was able to realise hepatic fibrosis evaluation. A case of co-infection HIV/OBI was noted. Conclusion: This study shows that in Bur- 
kina, almost half of blood bags transfused are anti-HBc positive and around one third (32.8\%) probably have HBV DNA. This poses a potential risk of contamination for non-immunized recipient. It is thus important that, in addition to HBsAg, Anti$\mathrm{HBc}$ should be systematically sought in order to minimize the risk.

\section{Keywords}

Occult Hepatitis B, Blood Donors, DNA, Anti-HBc

\section{Introduction}

Hepatitis B infection is a major public health problem. According to the World Health Organisation (WHO) two billions people are infected worldwide with 350 to 400 million individuals suffering from chronic hepatitis. One million deaths per year are attributable to cirrhosis and/or hepatocellular carcinoma resulting from this infection.

Since its discovery in 1965, hepatitis B surface antigen (HBsAg) is used as the fingerprint of hepatitis B infection (HBI). Occult hepatitis B described in the early 1980 corresponds to the presence of hepatitis $B$ virus DNA (deoxyribonucleic acid) in the serum and/or liver of patients in whom HBsAg is undetectable by usual serologic tests. In occult hepatitis $B$, the patients can have all the serologic profiles, of which the most frequent has been isolated anti-HBc antibodies, even anti-HBc and anti-HBs (cured hepatic profile), in an unusual way, isolated anti-HBs (vaccination profile); rarely the subject can be seronegative. The prevalence of occult hepatitis B infection (OBI) is highly variable since figures in the literature are ranged from 0 to $50 \%$ [1]. Coulibaly ML [2], Moresco M. Ndos S [3], Said ZN [4] and Oluyinka OO [5], in their studies, found that OBI's prevalence was respectively:

- $6.12 \%$ in a series of 147 haemodialysed patients;

- $2.7 \%$ samples were negative for HBsAg and positive for HBV DNA in 3600;

- $17 \%$ occult hepatitis B infection in blood donors;

- $17.2 \%$ occult hepatitis B infection in 3167 negative HBsAg donors.

Very low prevalence, $0.006 \%, 0.22 \%, 0.05 \%$ and $0.0006 \%$, was reported by Oluyinka OO et al. [5] in Poland, Italy, Spain and Germany respectively; they are low endemic countries for hepatitis B.

If the pathogenicity of occult hepatitis B remains disputable, however, we can individualise four particular situations which have an indisputable clinical significance and which remains the best confirmation of OBI reality.

1) The risk of blood transmission by donors with OBI is a reality. In fact, in 1978, Hoofnagle et al. [6] have described the transmission of a hepatitis B infection via the blood transfusion of a negative donor for HBsAg and anti-HBs antibodies but positive for anti-HBc antibodies.

2) The viral reactivation risk in the case of immunodepression (chemotherapy, graft of the kidney, of bone marrow, of the liver, immune deficits or new immunosuppres- 
sive therapy like anti-TNF), is principally in subjects with isolated anti-HBc;

3) Potential aggravation of fibrotic lesions is in case of HCV (hepatitis $\mathrm{C}$ viral) infection or associated cryptogenetic hepatic disease [7];

4) And finally, the real link is between hepatocellular carcinoma (HCC) and occult hepatitis B [1].

Burkina Faso is a high endemic area where the prevalence of hepatitis B viral infection is higher than 14\% [8] [9]. At the National Center for Blood Transfusion (NCBT) of Ouagadougou, HBsAg is the only sought marker used to distinguish donors towards hepatitis B viral (HBV) infection. Acceptation of blood donations based only on the absence of HBsAg exposes to the risk of HBV transmission during transfusion. The goal of this study was to evaluate this risk by determining the prevalence of OBI in anti$\mathrm{HBc}$ positive blood donors.

\section{Patients, Methods and Technics of Data Collection}

It is a five months prospective study on blood donations collected from January to May 2016.

\subsection{Patients}

Major subjects (18 years and above) voluntary blood donors were the concern of the study. Negative HBsAg and positive anti-HBc antibodies donors were included to this group. They were all contacted by phone to adhere to the study after explanation and invited to come for a consultation at the Hepato-gastroenterology unit of Yalgado Ouédraogo teaching hospital. Those who didn't come for consultation and those who were not in accordance with the study were excluded.

\subsection{Methods and Technics of Data Collection}

\section{Pre-donation medical interview}

Medical interview was the first obligatory step. It involves both qualified health personnel and donor candidate. It is a questionnaire to which candidates for blood donation are submitted. This interview consisted in finding eventual risk factors for the donor and for the recipient by identifying different pathologies transmissible or not which can develop in the donor and/or the recipient.

\section{Blood collection}

At the end of the medical interview, the candidate deemed fit for donation is taken to an appropriate room where blood is collected in individual bags identified by numbers, containing anticoagulant and conservative solution. Simultaneously, two biologic samples were collected in tubes. Different test were carried out on these samples for biologic qualification of the donation.

\section{Sample laboratory analysis}

The following tests were carried out on biologic samples contained in the tube: blood group ( $\mathrm{ABO}$ and Rhesus); the investigation of HBsAg, human immunodeficiency virus (HIV) antibodies, syphilis antibodies and hepatitis $\mathrm{C}$ virus (HCV) antibodies. These 
tests were carried out free of charge by NCBT laboratory.

\section{Results delivery}

Results of the tests carried out were available in about three weeks after the donation, and each donor was invited to come and collect his/her result at the Center of blood transfusion every afternoon of opened days.

\section{First phase of collection}

At the end of the first donation analysis, all negative HBsAg serums were selected for investigation of anti-HBc antibodies. The negative HBsAg serums and positive anti$\mathrm{HBc}$ antibodies were retained for the study.

\section{Specialized consultation}

The negative HBsAg donors with positive anti-HBc antibodies were consulted at the Hepato-gastroenterology unit of Yalgado Ouédraogo teaching hospital. The consultation comprises three steps:

A questionning on viral hepatitis particularly on hepatitis B concerning epidemiology, types of viruses, mode of contamination, evolution of HBV, treatment and means of prevention.

After a physical examination, a biologic assessment, comprising the viral load of $\mathrm{HBV}$ and the dosage of anti-HBs antibodies, were requested.

A questionnaire was administered at the end.

The second phase of data collection

It deals with donors who were received in external consultation and who gave their concerns. The viral load and titration of anti-HBs antibodies were requested after consultation. The cost of these additional tests was at the patient's charge.

\subsection{Markers Detection Tests}

The immunoenzymatic tests were used to detect HBsAg: Determine ${ }^{\mathrm{TM}}$ (Abbott) and Elisa (Vidas $)$ thanks to fourth $\left(4^{\text {th }}\right)$ generation reagents used on robot. The tests were used according to the manufacturer's instructions.

Rapid tests were used for anti-HBs antibodies: One Step HBc Ab (Serum/plasma). It is an immunochromatographic test which principle is the immunologic dosage in sandwich for the detection of anti-HBc antibodies in serum/plasma.

HBV DNA quantification was carried out using real time PCR in one of the four qualified laboratories of Ouagadougou chosen by patients, (CERBA, CHUYO, CMA Schiphra and "laboratoire d'analyses médicales du centre"). The detection points varied according to the type device used.

The DNA was considered as detectable if its level was superior to the manufacturer's detection threshold point (Table 1). Different Labs show a detection level higher than $10 \mathrm{IU} / \mathrm{ml}$ for ant-HBs antibodies, protective against HBV. Once the viral load was detectable, a complementary assessment was requested. It has consisted of a complete hepatic assessment (transaminase biologic tests, total bilirubin, alkaline phosphatases, gamma-glutamyl transpeptidase, alpha foeto-protein, full blood count, the Fibrometer ${ }^{ø} . .$. ), other HBV markers (HBeAg and anti-HBe antibodies), and morphologic ex- 
Table 1. Summary according to the type of device (robot) and the HBV DNA quantification points in the four laboratories.

\begin{tabular}{cccc}
\hline Laboratories & Devices (amplification/detection robot) & Lower detection point & Linearity point \\
\hline CENTRE & Cobas TaqMan HBV test & $6 \mathrm{IU} / \mathrm{ml}$ & $54-110,000,000 \mathrm{IU} / \mathrm{ml}$ \\
CERBA & Real time PCR/Applied biosystems 7500 platform & 2 Copies $/ \mathrm{ml}$ & $2-2 \times 10^{7} \mathrm{copies} / \mathrm{ml}$ \\
CHUYO & Automate CV: Abbott m2000rt & $10 \mathrm{IU} / \mathrm{ml}$ & $10-1000,000,000 \mathrm{IU} / \mathrm{ml}$ \\
SCHIPHRA & PCR temps réel TaqMan Roche & $20 \mathrm{U} / \mathrm{ml}$ & $20-170,000,000 \mathrm{IU} / \mathrm{ml}$ \\
\hline
\end{tabular}

aminations (abdominal ultrasound, abdominal CT scan, gastroscopy) related to the clinical context.

The patients were introduced in the HBV classical care system at the gastroenterology unit. The data collected were analysed using microcomputer with the aid of software like Epi info 3.5.4 (French version). The analysis of data collected used Epi info software (3.5.4 French version) on microcomputer.

\section{Results}

\subsection{Study Sample}

A total of 1980 serums from negative HBsAg donors were tested for anti-HBs antibodies, among which 872 (44\%) were positives. These 872 were called for specialized consultation and 160 responded. Among the 160 donors, 76 were able to realise DNA quantification which was detectable in 25 (32.8\%).

\subsection{Sociodemographic Characteristics}

The $32.8 \%$ OBI prevalence is shown (25 of the 76 who undertook the HBV DNA quantification). There were 20 men and 5 women given a sex ratio of 4 . The age range was 24 to 54 years old with a mean age of 33.15 years. The age class 21 to 30 was the most represented with 15 cases.

\subsection{Contamination Risks Factors}

Surgical and medical histories in favour of HBV transmission were found in donors (Table 2).

\subsection{Clinical Aspect}

The physical examination was normal in 25 donors.

\subsection{Paraclinical Feature}

The mean viral load was $954 \mathrm{IU} / \mathrm{ml}$ (5550 copies). A donor has a viral charge of 73672 $\mathrm{IU} / \mathrm{ml}$ (greater than $2000 \mathrm{IU} / \mathrm{ml}$ ).

Thirteen on twenty-five (52\%) had an anti-HBs level higher than $10 \mathrm{IU} / \mathrm{ml}$ (positive) and the twelve others had less than $10 \mathrm{IU} / \mathrm{ml}$ (negative).

$\mathrm{HBeAg}$ was negative in all the 25 while anti-HBe antibodies were positive in 18 cases.

Among the 25 donors, there was one HIV co-infection case and none of HCV infection. 
Table 2. Summary of risk factors.

\begin{tabular}{lc}
\hline Risk factors & Effectif \\
\hline Medical history & $\mathbf{8}$ \\
Icterus & 4 \\
Endoscopy & 2 \\
Blood transfusion & 2 \\
Surgical history & 10 \\
Surgical intervention & 3 \\
Circoncision & 7 \\
Female genital mutilation (FGM) & 3 \\
Dental care & 3 \\
Human bite & 3 \\
Scarification & 3 \\
Collective use of sharp objects & $\mathbf{8}$ \\
Nails clipper & 8 \\
Razor & 4 \\
Blade & 3 \\
\hline
\end{tabular}

\subsection{Other Complementary Examinations}

Hepatobiliary ultrasound done by 20 patients was normal. The biologic assessment highlights a moderate cytolysis of 2 times the normal upper limit at the expense of AST in the positive HIV patient. Alpha-fetoprotein and hepatic fibrosis were not assessed.

\section{Discussions}

Occult hepatitis B, defined as the presence of viral DNA in serum and/or liver in the absence of detectable HBsAg, was described in the late 1970s for the first time. However, it regains interest only during this last decade linked to the accentuation of security measures during transfusion and development in organ transplantations, mostly true in developed countries. Data on occult hepatitis B viral infection in developing countries are almost non-existent. In literature, the occult hepatitis B viral infection prevalence varies according to the detection method and the endemic level of the area [5] [10]. Burkina Faso is a high endemic area for hepatitis B with a prevalence higher than $14 \%$ [8] [9].

\subsection{Limitations of the Study}

Our study has some limitations. Despite our explanations in the phone to convince them, many anti-HBc positive donors did not see the need to come and visit. Among 872 donors called only 160 had responded. For them they are not seek and do not understand the need to spend their money in transport and additional tests. Otherwise the fact that the cost of the tests was in patient's charge (Vial load around \$100 US, an- 
ti-HBs $\$ 15$ US...) has been a strong bias of selection. Because only the donors able to pay their tests were included. Among 160 donors who responded only 76 were able to realize their tests and were really included in this study. We agree that there is probably a bias in this study.

\subsection{Prevalence}

Occult hepatitis B infection prevalence is highly variable (Table 3 ), since figures in the literature are ranged from 0 to $50 \%$ [1]. In our study, among 76 tested samples, 25 were found detectable thus an occult hepatitis B infection prevalence of $\mathbf{3 2 . 8 \%}$ in blood donors. Our result is higher than those of Coulibaly M L [2], Moresco M. Ndos S [3], Said $\mathrm{ZN} \mathrm{[4]} \mathrm{and} \mathrm{Oluyinka} \mathrm{OO} \mathrm{[5]} \mathrm{in} 2015$ whose prevalence were respectively:

- $6.12 \%$ in a series of 147 haemodialysed patients;

- $2.7 \%$ samples were negative for HBsAg and positive for HBV DNA in 3600;

- $17 \%$ occult hepatitis B infection in blood donors;

- $\quad 17.2 \%$ occult hepatitis B infection in 3167 negative HBsAg donors.

Prevalence lower than that of our study: $0.006 \%, 0.22 \%, 0.05 \%$ and $0.0006 \%$ were reported by Oluyinka OO et al. [5] in Poland, Italy, Spain and Germany respectively; they are low endemic countries.

The high prevalence of occult hepatitis B infection in our study can be attributable to the fact that Burkina Faso belongs to a high HBV endemic area, the small tested sample size for DNA and also the improvement in more sensitive DNA detection technics (real time PCR). This poses a real problem of transfusion security in our countries. HBsAg was the only sought marker to distinguish donors, it is true that blood bags containing viral DNA are transfused everyday here in Burkina Faso to recipients who are mostly children suffering from severe anaemia particularly due to malaria.

\subsection{Anti-HBc Antibodies}

In our study, we have noted an anti-HBc antibodies portage prevalence of $44 \%$ (872/1980) in negative HBsAg donors. Barro L [11], also found a portage prevalence of 38.07\% in negative HBsAg donors in 2014 in Burkina, while in 2015 in Cameroon, Biwole reported a higher anti-HBc antibodies portage prevalence of $57 \%$ in a similar population.

The presence of anti-HBc antibodies shows that there was a contact with the HBV, be it a chronic hepatitis B (positive HBsAg for more than 6 months with positive anti-HBc antibodies) or occult hepatitis B infection (negative HBsAg with detectable DNA) or a cured hepatitis B (negative HBsAg, undetectable DNA and positive anti-HBc antibodies). Any positive anti- $\mathrm{HBc}$ antibodies patient is prone to a reactivation of hepatitis $B$ in case of immunodepression, be it iatrogenic (chemotherapy, organ transplantation) or acquired (HIV infection).

\subsection{Sociodemographic Characteristics}

The age range was 24 to 54 years old with a mean age was 33.15 years. The sex ratio was 
Table 3. Occult HB viral infection prevalence reported by other authors.

\begin{tabular}{|c|c|c|c|c|c|}
\hline Studies & Countries & Patients(n) & O B I n (\%) & Methods & HBV endemic level \\
\hline Said ZN 2013 [10] & Egypt & 3167 donors HBsAg (-) & $17.2 \%$ & PCR RT (QIAGEN) & High \\
\hline Fabrizi 2005 [14] & Italy & 213 & 0 & Single step PCR & Low \\
\hline Filippini 2006 [15] & Italy & $86 \mathrm{HIV}$ & $17(20)$ & Single step PCR & Low \\
\hline Rodriguez-2007 [16] & $\begin{array}{l}19 \text { countries } \\
\text { (Apricot) }\end{array}$ & $889 \mathrm{HCV}+\mathrm{HIV}+$ & 0 & PCR Roche & \\
\hline
\end{tabular}

HB: hepatitis B; OBI: occult hepatitis B infection; PCR: "polymerase chain reaction"; RT: "real time"; HCV: "hepatitis C virus"; HIV: "human immunodeficiency virus".

4. The male predominance is due to the fact that females generally participate poorly to blood donation and also to the high cost of complementary exams. The fact that tests cost was borne by patient constituted a real selection bias.

\subsection{Risk Factors (Table 2)}

Surgical and medical histories in favour of HBV transmission were found in donors. Collective use of sharp objects was noted. Nails clipper (8 donors), razor (4 donors), blade ( 3 donors) and some harmful traditional practices such as female genital mutilation which had been performed in 3 women of our study.

These practices in our regions contribute to promote and maintain the transmission of HBV and other diseases transmissible via biologic fluids.

\subsection{Clinical Feature}

Hepathopatic signs were not noted in our study. However, the following clinical situations could be some circumstances of occult hepatitis B discovery

Transmission of occult hepatitis $B$ viral infection to a recipient

During assessment of hepatitis; it is generally acute in a recipient. Post-transfusion risk in France is $1 / 450000$ (2 times higher to that of hepatitis $\mathrm{C}$ and 4 times higher to that of HIV). This HBV transmission risk to positives anti-HBs antibodies subjects was demonstrated [6].

Reactivation of an occult hepatitis $B$ viral infection is described in literature during an immunosuppression in case of chemotherapy, graft (kidney, bone marrow, liver) and immune deficiencies [18]. Vallet-Pichard A and Pol S, in 2008 found a viral reactivation frequency of $0.5 \%$ in renal transplantation and of $5 \%$ in hematopoietic stem cells graft in recipients with positive anti-HBc antibodies [1].

Chronic diseases of the liver and occult hepatitis $B$ viral infection 
We did not evaluate fibrosis in our study; however, no evocative sign of chronic hepatopathy was noted during clinical examination and ultrasound.

Occult hepatitis B viral infection in hemodialysed patients

Many studies confirm a relatively high frequency of occult hepatitis B viral infection in hemodialysed patients [2] [19]

Hepatocellular carcinoma (HCC) [20]

No case of HCC was noted in our study on condition of the anatomo-pathologic test which was not carried out in our patients. The occult hepatitis B viral infection prevalence varies from $10 \%-60 \%$ and even more in case of HCC with unknown aetiology [1].

\subsection{Paraclinical Feature}

Occult hepatitis B is a complex biologic entity.

Viral charge (viral $D N A$ )

About two third (50/76) of viral charges were carried out using PCR/Applied biosystems 7500 platform technic. The detection point with this technic was the lowest (lower detection limit is at 02 copies $/ \mathrm{ml}$ ) of the four used technics (Table 1). For 25 cases of detectable DNA in this study, the HBV viral charges were ranged between 2.23 and $3672.68 \mathrm{IU} / \mathrm{ml}$ with a mean value of $954 \mathrm{IU} / \mathrm{ml}$ corresponding to $13-428775$ copies $/ \mathrm{ml}$ with a mean value of 5550 copies $/ \mathrm{ml}$. Only one donor had a viral charge greater than $2000 \mathrm{IU} / \mathrm{ml}$ (73,672 IU/ml). In Nigeria, Oluyinka O [5] reported a viral charge comprised between 18.4 and $224.3 \mathrm{IU} / \mathrm{ml}$ and one of his patients had a viral charge greater than 4000 IU. Candotti et al. [21] noted a viral charge between undetectable and 5640 $\mathrm{IU} / \mathrm{ml}$ with a median of $25 \mathrm{IU} / \mathrm{ml}$ in Europe. Viral charge is generally low in literature in case of occult hepatitis B (less than 4 logs) [1] [22]. Sequencing of HBV was not carried out in our series, but Allain J P et al. [23] found predominance of genotype A and genotype D.

\section{Anti-HBs antibody}

In our study, thirteen donors on twenty-five (52\%) had an anti-HBs antibodies level greater than $10 \mathrm{IU} / \mathrm{ml}$. Raimondo G. [24] found among his anti-HBs antibodies carriers that $75 \%$ had protective concentration ( $>10 \mathrm{IU} / \mathrm{ml}$ ) while Oluyinka O et al. [5] reported a protective anti-HBs antibodies percentage of $30 \%$.

\section{Anti-HBc antibody}

We noted an anti-HBc antibodies portage prevalence of $44 \%(872 / 1980)$. This high portage prevalence of anti-HBc antibodies were seen in many series mostly in high endemic countries [20] [25] [26]. Oluyinka $\mathrm{O}$ [5] reported a portage prevalence of $43.05 \%$ in donors in Nigeria while that of Said Z N [10] in Egypt was lower, 14.2\%. We think that anti-HBc antibodies portage is the enlarged reflection of the prevalence of hepatitis $\mathrm{B}$ in a given area. OBI prevalence is high in subjects with positive anti-HBc antibodies especially in the absence of anti-HBs antibodies.

Other complementary tests

A case of HIV/HBV co-infection with a viral charge HBV at 420 copies was noted. 
The standard biologic assessment of the liver (transaminases, bilirubin, gamma glutamyl transpeptidase, alkaline phosphatases, prothrombin levels...) was normal even hepato-biliary ultrasound. Occult hepatitis B is a chronic hepatitis usually inactive.

\section{Conclusion}

Occult hepatitis B is frequent in high endemic areas, but usually latent in the absence of cofactors particularly immunodepression states. Prevention of HBV transmission through blood transfusion relies on the reinforcement of transfusion security by eliminating all positive donors for anti-HBc. This will lead to a drastic decrease of blood products which are already insufficient in high HBV and HIV endemic areas, but that's the price to be paid for transfusion security. Accurate screening and vaccination of neonates are the cornerstones of prevention against HBV.

\section{References}

[1] Vallet-Pichard, A. and Pol, S. (2008) L’hépatite B occulte. Virologie, 12, 87-94.

[2] Coulibaly, M.L. (2014) Etude de la prévalence de l'infection VHB occulte chez les patients hémodialysés. Archive Ouverte UM5-Rabat 2014, 123.

[3] Moresco, M.N. dos S., Virgolino, H. de A., Morais, M.P.E., Motta-Passos, I. da, GomesGouvêa, M.S., de Assis, L.M.S., de L. Aguiar K.R. and Lombardi, S.C.F. (2014) Occult Hepatitis B Virus Infection among Blood Donors from the Brazilian Amazon: Implications for Transfusion Policy. Vox Sanguinis, 107, 19-25. http://dx.doi.org/10.1111/vox.12125

[4] Said, Z.N. (2011) An Overview of Occult Hepatitis B Virus Infection. World Journal of Gastroenterology, 17, 1927-1938. http://dx.doi.org/10.3748/wjg.v17.i15.1927

[5] Oluyinka, O.O., Tong, H.V., Bui Tien, S., Fagbami, A.H., Adekanle, O., Ojurongbe, O., et al. (2015) Occult Hepatitis B Virus Infection in Nigerian Blood Donors and Hepatitis B Virus Transmission Risks. PLOS One, 10, e0131912. http://dx.doi.org/10.1371/journal.pone.0131912

[6] Hoofnagle, J.H., Seeff, L.B., Bales, Z.B. and Zimmerman, H.J. (1978) Type B Hepatitis after Transfusion with Blood Containing Antibody to Hepatitis B Core Antigen. The New England Journal of Medicine, 298, 1379-1383. http://dx.doi.org/10.1056/NEJM197806222982502

[7] Goral, V., Ozkul, H., Tekes, S., Sit, D. and Kadiroglu, A.K. (2006) Prevalence of Occult HBV Infection in Haemodialysis Patients with Chronic HCV. World Journal of Gastroenterology, 12, 3420-3124. http://dx.doi.org/10.3748/wjg.v12.i21.3420

[8] Sombié, R., Bougouma, A., Diallo, O., et al. (2010) Hépatite B chronique: Aspects épidémiologique, diagnostique, thérapeutique et évolutif au centre hospitalier universitaire Yalgado Ouédraogo de Ouagadougou. Journal Africain d'Hépato-Gastroentérologie, 4, 3-10. http://dx.doi.org/10.1007/s12157-009-0137-2

[9] Tao, I., Compaoré, T.R., Diarra, B., et al. (2014) Seroepidemiology of Hepatitis B and C Viruses in the General Population of Burkina Faso. Hindawi Publishing Corporation Hepatitis Research and Treatment, 2014, Article ID: 781843, 5 p.

[10] Said, Z.N., et al. (2013) Occult Hepatitis "B” Virus Infection among Egyptian Blood Donors. World Journal of Hepatology, 5, 64-73. http://dx.doi.org/10.4254/wjh.v5.i2.64

[11] Barro, L. (2014) Problématique de la sécurité transfusionnelle au Burkina Faso: Le dépistage de l'anticorps de core du virus de l'hépatite B (Ac anti-HBc) serait-il un examen de trop? 
Master Complémentaire en médecine transfusionnelle, université de Liège, $40 \mathrm{p}$.

[12] Siagris, D., Christofidou, M., Triga, K., et al. (2006) Occult Hepatitis B Virus Infection in Hemodialysis Patients with Chronic HCV Infection. Journal of Nephrology, 19, 327-333.

[13] Kanbay, M., Gur, G., Akcay, A., et al. (2006) Is Hepatitis C Virus Positivity a Contributing Factor to Occult Hepatitis B Virus Infection in Hemodialysis Patients? Digestive Diseases and Sciences, 51, 1962-1966. http://dx.doi.org/10.1007/s10620-006-9421-9

[14] Fabrizi, F., Messa, P.G., Lunghi, G., et al. (2005) Occult Hepatitis B Virus Infection in Dialysis Patients: A Multicentre Survey. Alimentary Pharmacology \& Therapeutics, 21, 13411347. http://dx.doi.org/10.1111/j.1365-2036.2005.02501.x

[15] Filippini, P., Coppola, N., Pisapia, R., et al. (2006) Impact of Occult Hepatitis B Virus Infection in HIV Patients Naive for Antiretroviral Therapy. AIDS, 20, 1253-1260. http://dx.doi.org/10.1097/01.aids.0000232232.41877.2a

[16] Rodriguez-Torres, M., Gonzalez-Garcia, J., Brau, N., et al. (2007) Occult Hepatitis B Virus Infection in the Setting of Hepatitis C Virus and Human Immunodeficiency Virus Co-Infection: Clinically Relevant or a Diagnosis Problem? Journal of Medical Virology, 79, 694700. http://dx.doi.org/10.1002/jmv.20836

[17] Kim, S.M., Lee, K.S., Park, C.J., et al. (2007) Prevalence of Occult Hepatitis B Infection among Subjects with Normal ALT Levels in Korea. Journal of Infection, 54, 185-191. http://dx.doi.org/10.1016/j.jinf.2006.02.002

[18] Hollinger, F.B. and Sood, G. (2010) Occult Hepatitis B Virus Infection: A Covert Operation. Journal of Viral Hepatitis, 17, 1-15. http://dx.doi.org/10.1111/j.1365-2893.2009.01245.x

[19] Yoo, J.H., Hwang, S.G., Yang, D.H., et al. (2013) Prevalence of Occult Hepatitis B Virus Infection in Hemodialysis Patients. Korean Journal of Gastroenterology, 61, 209-214. http://dx.doi.org/10.4166/kjg.2013.61.4.209

[20] Shi, Y., Wu, Y.H., Wu, W., et al. (2012) Association between Occult Hepatitis B Infection and the Risk of Hepatocellular Carcinoma: A Meta-Analysis. Liver International, 32, 231240. http://dx.doi.org/10.1111/j.1478-3231.2011.02481.x

[21] Candotti, D. and Allain, J.P. (2009) Transfusion-Transmitted Hepatitis B Virus Infection. Journal of Hepatology, 51, 798-809. http://dx.doi.org/10.1016/j.jhep.2009.05.020

[22] Mehdi, Z. (2013) Occult Hepatitis B: Clinical Viewpoint and Management. Hepatitis Research and Treatment, 2013, Article ID: 259148.

[23] Allain, J.P., Belkhiri, D., Vermeulen, M., Crookes, R., Cable, R., Amiri, A., et al. (2009) Characterization of Occult Hepatitis B Virus Strains in South African Blood Donors. Journal of Hepatology, 49, 1868-1876. http://dx.doi.org/10.1002/hep.22879

[24] Raimondo, G., Pollicino, T., Romano, L. and Zanetti, A.R. (2010) A 2010 Update on Occult Hepatitis B Infection. Pathologie Biologie, 58, 254-257. http://dx.doi.org/10.1016/j.patbio.2010.02.003

[25] Biwole Sida, M., Jeatsa Gapdo, C., Mbangue, M., Essola, J., Leundji, H. and Dissongoii, J. (2015) Prévalence de l'Anticorps $\mathrm{HBc}$ chez les donneurs de sang AgHBs négatifs à l'hôpital Laquintinie de Douala. Health Sciences and Disease, 16, 1-4.

[26] Pietra, V., Kiema, D., Sorgho, D., Kaboré, S.-P.C.G., Mandé, S., Castelli, F., Puoti, M. and Simporé, J. (2008) Prévalence des marqueurs du virus de l'hépatite B et des anticorps contre le virus de l'hépatite C parmi le personnel du District Sanitaire de Nanoro, Burkina Faso. Science et Technique, 31, 53-59. 
Submit or recommend next manuscript to SCIRP and we will provide best service for you:

Accepting pre-submission inquiries through Email, Facebook, LinkedIn, Twitter, etc.

A wide selection of journals (inclusive of 9 subjects, more than 200 journals)

Providing 24-hour high-quality service

User-friendly online submission system

Fair and swift peer-review system

Efficient typesetting and proofreading procedure

Display of the result of downloads and visits, as well as the number of cited articles

Maximum dissemination of your research work

Submit your manuscript at: http://papersubmission.scirp.org/

Or contact ojgas@scirp.org 